\title{
Enhanced citric acid biosynthesis in Pseudomonas fluorescens ATCC 13525 by overexpression of the Escherichia coli citrate synthase gene
}

Correspondence

G. Naresh Kumar

gnk_mmbl@yahoo.co.in

Received 3 March 2009

Revised 8 May 2009

Accepted 12 May 2009

\author{
Aditi D. Buch, ${ }^{1}$ G. Archana ${ }^{2}$ and G. Naresh Kumar $^{1}$ \\ ${ }^{1}$ Molecular Microbial Biochemistry Laboratory, Department of Biochemistry, Faculty of Science, \\ M. S. University of Baroda, Vadodara 390 002, India \\ ${ }^{2}$ Department of Microbiology and Biotechnology Center, Faculty of Science, M. S. University of \\ Baroda, Vadodara 390 002, India
}

\begin{abstract}
Citric acid secretion by fluorescent pseudomonads has a distinct significance in microbial phosphate solubilization. The role of citrate synthase in citric acid biosynthesis and glucose catabolism in pseudomonads was investigated by overexpressing the Escherichia coli citrate synthase ( $\mathrm{g} / \mathrm{tA}$ ) gene in Pseudomonas fluorescens ATCC 13525. The resultant $\sim 2$-fold increase in citrate synthase activity in the $g / t A$-overexpressing strain $P f(p A B 7)$ enhanced the intracellular and extracellular citric acid yields during the stationary phase, by about 2- and 26-fold, respectively, as compared to the control, without affecting the growth rate, glucose depletion rate or biomass yield. Decreased glucose consumption was paralleled by increased gluconic acid production due to an increase in glucose dehydrogenase activity. While the extracellular acetic acid yield increased in Pf(pAB7), pyruvic acid secretion decreased, correlating with an increase in pyruvate carboxylase activity and suggesting an increased demand for the anabolic precursor oxaloacetate. Activities of two other key enzymes, glucose-6-phosphate dehydrogenase and isocitrate dehydrogenase, remained unaltered, and the contribution of phosphoenolpyruvate carboxylase and isocitrate lyase to glucose catabolism was negligible. Strain Pf(pAB7) demonstrated an enhanced phosphate-solubilizing ability compared to the control. Co-expression of the Synechococcus elongatus PCC 6301 phosphoenolpyruvate carboxylase and E. coli gltA genes in P. fluorescens ATCC 13525, so as to supplement oxaloacetate for citrate biosynthesis, neither significantly affected citrate biosynthesis nor caused any change in the other physiological and biochemical parameters measured, despite approximately 1.3- and 5-fold increases in citrate synthase and phosphoenolpyruvate carboxylase activities, respectively. Thus, our results demonstrate that citrate synthase is rate-limiting in enhancing citrate biosynthesis in $P$. fluorescens ATCC 13525. Significantly low extracellular citrate levels as compared to the intracellular levels in Pf(pAB7) suggested a probable limitation of efficient citrate transport.
\end{abstract}

\section{INTRODUCTION}

Most phosphate-solubilizing bacteria (PSB) solubilize mineral phosphates by secreting a variety of organic acids, principally gluconic acid. However, the nature and amount of organic acids limit the efficacy of PSB in soils and in field conditions (Kucey et al., 1989; Gyaneshwar et al., 2002; Khan et al., 2007; Srivastava et al., 2006). Organic

Abbreviations: CS, citrate synthase; dcw, dry cell weight; G-6-PDH, glucose-6-phosphate dehydrogenase; $\mathrm{GDH}$, glucose deydrogenase; $I C D H$, isocitrate dehydrogenase; ICL, isocitrate lyase; OAA, oxaloacetate; PPC, phosphoenolpyruvate carboxylase; PSB, phosphate-solubilizing bacteria; PYC, pyruvate carboxylase.

A supplementary figure showing the effect of $p p c-g / t A$ co-expression on organic acid secretion by $P$. fluorescens 13525 is available with the online version of this paper. acids at concentrations ranging from 10 to $100 \mathrm{mM}$ are required to release phosphate from alkaline soils, citric acid being the most effective (Gyaneshwar et al., 1998; Srivastava et al., 2006). Of the known PSB, several strains of Bacillus sp. and Citrobacter koseri have been reported to secrete citric acid along with various other organic acids (Gyaneshwar et al., 1998). Apart from mineral phosphate solubilization, citric acid secretion by PSB could also be implicated in mediating aluminium tolerance, as in Pseudomonas fluorescens ATCC 13525 (Mailloux et al., 2008), and as a siderophore, as in Bradyrhizobium and Pseudomonas aeruginosa (Guerinot et al., 1990; Carson et al., 1992; Marshall et al., 2009).

Citric acid biosynthesis involves condensation of oxaloacetate (OAA) and acetyl-CoA catalysed by the ubiquitous 
citrate synthase (CS), a key non-redundant enzyme governing the carbon flux into the tricarboxylic acid (TCA) cycle, with a dual function of producing cellular energy and biosynthetic precursors (Park et al., 1994). However, despite its key position, no direct correlation has been demonstrated between CS activity and bacterial citric acid accumulation. Genetic modifications leading to citric acid accumulation in bacteria include isocitrate dehydrogenase $(\mathrm{ICDH})$ mutation in Escherichia coli ( $\mathrm{K}$ and $\mathrm{B}$ strains) and Bacillus subtilis (in early stationary phase) as well as aconitase mutation in Streptomyces coelicolor (Lakshmi \& Helling, 1976; Matsuno et al., 1999; Viollier et al., 2001; Aoshima et al., 2003; Kabir \& Shimizu, 2004).

Fluorescent pseudomonads are well-known plant-growthpromoting rhizobacteria with high biocontrol efficacy as well as phosphate-solubilizing ability (Rodríguez \& Fraga, 1999; Haas \& Défago, 2005). Distinct metabolic features in pseudomonads make them an attractive model for genetic modifications targeting citric acid accumulation. Unlike citric-acid-accumulating bacteria such as E. coli and Bacillus, which utilize glucose via the EmbdenMeyerhoff-Parnas pathway, pseudomonads utilize glucose by two different routes: the periplasmic direct oxidation pathway mediated by pyrroloquinoline-quinone-dependent glucose dehydrogenase (PQQ-GDH) and intracellular phosphorylative oxidation mediated by glucokinase and glucose-6-phosphate dehydrogenase (G-6-PDH), ultimately followed by the Entner-Doudoroff pathway (Lessie \& Phibbs, 1984). The control of glycolytic flux mediated by allosterically regulated phosphofructokinase is not possible in pseudomonads, because they lack this enzyme (Lessie \& Phibbs, 1984). Other metabolic advantages include high carbon flux through the TCA cycle resulting in lower acetate overflow and increased capacity to produce OAA due to the presence of pyruvate carboxylase (PYC) and/or phosphoenolpyruvate carboxylase (PPC) at the anaplerotic node, availability of a citrate transporter and absence of glucose-mediated catabolite repression (Lessie \& Phibbs, 1984; Stover et al., 2000; Nelson et al., 2002; Basu et al., 2006). Thus, CS activity could limit citric acid biosynthesis in pseudomonads.

This paper describes the effect of overexpression of the $E$. coli citrate synthase $(\mathrm{glt} A)$ gene on glucose metabolism and citrate levels in P. fluorescens ATCC 13525.

\section{METHODS}

Materials and chemicals. Luria-Bertani broth and Pseudomonas agar for culture maintenance; D-glucose, Tris base, phenazine methosulphate (for GDH assay), cysteine. $\mathrm{HCl}$, phenylhydrazine, oxaloacetate, 5,5'-dithiobis(2-nitrobenzoic acid), Folin-Ciocalteau reagent, HPLC-grade acetonitrile and other routine analytical-grade salts and organic acids were procured from Sisco Research Laboratories, Qualigens Fine Chemicals and Merck. NADH, NADP, acetyl-CoA (sodium salt), phosphoenolpyruvate (monopotassium salt), isocitrate, 2,6-dichlorophenolindophenol (sodium salt; for GDH assay), glucose 6-phosphate (for G-6-PDH assay), and the enzymes malate dehydrogenase (porcine heart), lactate dehydrogenase and citrate lyase were obtained from Sigma. Restriction enzymes and T4 DNA ligase were purchased from Bangalore Genei and used according to the manufacturers' instructions.

Bacterial strains, plasmids and culture conditions. $E$. coli and $P$. fluorescens strains used for this work are listed in Table 1. E. coli JM101 was used as the host strain for all the DNA manipulation and molecular biology experiments, using standard protocols (Sambrook \& Russell, 2001). The gltA (citrate synthase gene) mutant of E. coli, W620, was obtained from the E. coli Genetic Stock Center (CGSC), Yale University, USA. The E. coli gltA gene cloned in pBluescriptSK(-) was a generous gift from Dr E. Delhaize, CSIRO Plant Industry, Australia; plasmid pYanni3 was kindly gifted by $\mathrm{Dr}$ D. W. Wackernagel, University of Oldenberg, Germany. The Pseudomonas stable pUCPM18 plasmid was generously gifted by Dr J. Sokatch, University of Oklahoma Health Sciences, USA, and was used to derive recombinant plasmids pAB7 and pAB8 (Table 1). Physiological studies were carried out using P. fluorescens ATCC 13525.

E. coli plasmid transformants were routinely grown at $37{ }^{\circ} \mathrm{C}$ and maintained on Luria-Bertani agar; P. fluorescens ATCC 13525 and its plasmid-bearing derivatives were grown at $30{ }^{\circ} \mathrm{C}$ and maintained on Pseudomonas agar. For both E. coli and P. fluorescens, the final concentrations of antibiotics were $30 \mu \mathrm{g}$ tetracycline $\mathrm{ml}^{-1}$ and $50 \mu \mathrm{g}$ kanamycin $\mathrm{ml}^{-1}$, respectively, as and when required.

Construction of PAB7 with the $E$. coli gltA gene under the lac promoter. The E. coli gltA gene was obtained as a 1312 bp DNA fragment by digesting plasmid pCS-Ec (4237 bp) with SacI and $B a m \mathrm{HI}$. The fragment was gel eluted, purified and ligated to purified SacI/BamHI-digested plasmid pUCPM18 (5349 bp). The resultant plasmid pAB6 (6646 bp) containing the inserted gltA gene in the correct orientation with respect to the lac promoter of pUCPM18 was identified by restriction pattern. Subsequently, a kanamycin resistance gene (nptII) was incorporated in pAB6 in order to provide an appropriate selection marker for Pseudomonas transformants. The requisite $n p t I I$ gene was obtained as a purified 1637 bp DNA fragment by digesting plasmid pYanni3 (7535 bp) with XhoI/HindIII and was ligated to SalI/HindIII-digested pAB6 to yield pAB7 (8265 bp). The desired plasmid was selected as kanamycin-resistant colonies on LuriaBertani agar and was confirmed by restriction digestion pattern. Plasmid pAB7 was separately digested with XbaI to release a 1294 bp gltA gene fragment and the remaining plasmid backbone was selfligated to obtain pAB8 $(6971 \mathrm{bp})$, containing only the nptII gene in pUCPM18; pAB8 was used as the control plasmid for all experiments.

Development of $P$. fluorescens ATCC 13525 harbouring the gitA gene independently and in combination with the Synechococcus elongatus PCC 6301 ppc gene. P. fluorescens ATCC 13525 was independently transformed with plasmids pAB7 and pAB8 by using the $\mathrm{NaCl} / \mathrm{CaCl}_{2}$ method (Cohen et al., 1972) to obtain strain $P f(\mathrm{pAB} 7)$, expressing E. coli gltA, and its corresponding plasmid control, $P f(\mathrm{pAB} 8)$. $P$. fluorescens ATCC 13525 co-expressing the $p p c$ and gltA genes, $P f(\mathrm{pAB} 37)$, and its double transformant control, $P f(\mathrm{pAB} 48)$, were developed by similarly transforming $P f(\mathrm{pAB} 3)$, expressing S. elongatus PCC $6301 p p c$, and its control Pf(pAB4), with plasmids $\mathrm{pAB} 7$ and $\mathrm{pAB} 8$, respectively. The single transformants were selected on Pseudomonas agar containing kanamycin while double transformants were similarly selected on kanamycin and tetracycline.

Physiological experiments and phosphate solubilization. Fresh cell cultures grown with overnight shaking at $30{ }^{\circ} \mathrm{C}$ in $3 \mathrm{ml}$ LuriaBertani broth were aseptically harvested, repeatedly washed with sterile $0.9 \%(\mathrm{w} / \mathrm{v})$ saline and resuspended in $1 \mathrm{ml}$ of the same under sterile conditions. The resultant bacterial cell suspension was used to inoculate M9 minimal medium supplemented with $100 \mathrm{mM}$ glucose and micronutrient cocktail (Sambrook \& Russell, 2001) to give an 
Table 1. Bacterial strains and plasmids used in this study

Ap, ampicillin; Km, kanamycin; Str, streptomycin; Tc, tetracycline.

\begin{tabular}{|c|c|c|}
\hline Plasmid/strain & Relevant characteristics & Source/reference \\
\hline \multicolumn{3}{|l|}{ Plasmids } \\
\hline pUCPM18 & Broad-host-range cloning vector, $\mathrm{Ap}^{\mathrm{r}}$ & Hester et al. (2000) \\
\hline pYanni3 & Cloning vector, $\mathrm{Km}^{\mathrm{r}}$ & W. Wackernagel \\
\hline pCS-Ec & E. coli gltA cloned in pBluescriptSK(-), $\mathrm{Ap}^{\mathrm{r}}$ & E. Delhaize \\
\hline pAB8 & pUCPM18 with $n p t I I$ gene, $\mathrm{Ap}^{\mathrm{r}} / \mathrm{Km}^{\mathrm{r}}$ & This study \\
\hline pAB7 & gltA gene of E. coli in $\mathrm{pAB} 8, \mathrm{Ap}^{\mathrm{r}} / \mathrm{Km}^{\mathrm{r}}$ & This study \\
\hline \multicolumn{3}{|l|}{ Strains } \\
\hline \multicolumn{3}{|l|}{ E. coli } \\
\hline JM101 & $\mathrm{F}^{\prime}$ traD36 $\operatorname{proA}^{+} B^{+}$lac $^{q} \Delta($ lacZ) $\mathrm{M} 15 / \Delta$ (lac-proAB) $\operatorname{gln} V$ thi & Sambrook \& Russell (2001) \\
\hline W620 & CGSC 4278 glnV44 gltA6 galK30 LAM-pyrD36 relA1 rpsL129 thi-1, Str ${ }^{\mathrm{r}}$ & E. coli Genetic Stock Center \\
\hline \multicolumn{3}{|c|}{ 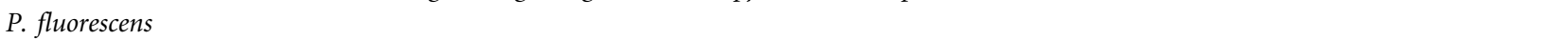 } \\
\hline 13525 & Wild-type & ATCC \\
\hline$P f(\mathrm{pAB} 3)$ & $\begin{array}{l}\text { P. fluorescens } 13525 \text { with pAB3 containing S. elongatus PCC } 6301 \text { ppc gene } \\
\text { under lac promoter, } \mathrm{Tc}^{\mathrm{r}}\end{array}$ & Authors' unpublished results \\
\hline$P f(\mathrm{pAB} 4)$ & P. fluorescens 13525 with pAB4 control plasmid, $\mathrm{Tc}^{\mathrm{r}}$ & Authors' unpublished results \\
\hline$P f(\mathrm{pAB} 8)$ & P. fluorescens 13525 with $\mathrm{pAB} 8, \mathrm{Km}^{\mathrm{r}}$ & This study \\
\hline$P f(\mathrm{pAB} 7)$ & P. fluorescens 13525 with pAB7, $\mathrm{Km}^{\mathrm{r}}$ & This study \\
\hline$P f(\mathrm{pAB} 48)$ & P. fluorescens 13525 with $\mathrm{pAB} 8$ and $\mathrm{pAB} 4, \mathrm{Km}^{\mathrm{r}} / \mathrm{Tc}^{\mathrm{r}}$ & This study \\
\hline$P f(\mathrm{pAB} 37)$ & P. fluorescens 13525 with $\mathrm{pAB} 7$ and $\mathrm{pAB} 3, \mathrm{Km}^{\mathrm{r}} / \mathrm{Tc}^{\mathrm{r}}$ & This study \\
\hline
\end{tabular}

initial cell density of $\mathrm{OD}_{600} 0.01-0.03\left(\sim 2 \times 10^{6}\right.$ c.f.u. $\left.\mathrm{ml}^{-1}\right)$. Batch culture studies were performed by shaking $150 \mathrm{ml}$ conical flasks with $30 \mathrm{ml}$ of the inoculated medium on an Orbitek rotary shaker at $30{ }^{\circ} \mathrm{C}$ and 200 r.p.m. Antibiotics were added to a final concentration of $12.5 \mu \mathrm{g}$ kanamycin $\mathrm{ml}^{-1}$ and $7.5 \mu \mathrm{g}$ tetracycline $\mathrm{ml}^{-1}$, as and when required.

Dicalcium-phosphate-solubilizing ability of the gltA transformants of P. fluorescens ATCC 13525 was tested on Pikovskaya's agar (Pikovskaya, 1948). Three microlitres of the bacterial inoculum was aseptically spotted on the agar plates and was allowed to dry completely followed by incubation at $30{ }^{\circ} \mathrm{C}$. Ability to release inorganic phosphate from rock phosphate was monitored using TRP minimal medium as described by Buch et al. (2008), with the modification that $25 \mathrm{mM}$ Tris/ $\mathrm{HCl}(\mathrm{pH} 8.0)$ was used instead of $100 \mathrm{mM}$ Tris/ $\mathrm{HCl}$ ( $\mathrm{pH}$ 8.0). Preparation of bacterial inocula for phosphate-solubilization studies was similar to that for the abovementioned physiological experiments. Phosphate solubilization on Pikovskaya's agar was determined by monitoring the zone of clearance, and a decrease in the $\mathrm{pH}$ of the medium from 8.0 to $<5$ in TRP broth was used to indicate rock phosphate solubilization.

Analytical techniques. Change in cell density, determined as $\mathrm{OD}_{600}$ (Helios $\gamma$ spectrophotometer, Thermo Spectronics), was used as the measure of growth while decrease in $\mathrm{pH}$ of the medium was used as the measure of acid production. The observations were continued until the medium $\mathrm{pH}$ was $<5$. Samples $(1 \mathrm{ml})$, withdrawn aseptically at regular time intervals, were centrifuged at $9200 \mathrm{~g}$ for $1 \mathrm{~min}$ at $4{ }^{\circ} \mathrm{C}$ and were immediately frozen at $-20{ }^{\circ} \mathrm{C}$ until further used for biochemical estimations. The culture supernatants derived from these samples were used to measure residual glucose concentration in the medium using a GOD-POD kit (Enzopak, Reckon Diagnostics). The culture supernatants derived at the end-point of the experiment $(\mathrm{pH}$ $<5$ ) were passed through $0.2 \mu \mathrm{m}$ pore-size nylon membranes (MDI Advanced Microdevices) and used for organic acid analysis by HPLC. The secreted organic acids were identified and quantified using a Varian Microsorb Rphosphate-18 column operated at room temperature using a mobile phase of $0.01 \mathrm{M} \mathrm{H}_{2} \mathrm{SO}_{4}$ at a flow rate of $1.0 \mathrm{ml}$ $\min ^{-1}$ and the column effluents were monitored using a UV detector at $210 \mathrm{~nm}$ (Buch et al., 2008). For citric acid estimation, the same column was operated at room temperature using a mobile phase of $20 \mathrm{mM} \mathrm{Na}_{2} \mathrm{HPO}_{4}$ with $2.5 \%(\mathrm{v} / \mathrm{v})$ acetonitrile at a flow rate of $1.0 \mathrm{ml}$ $\mathrm{min}^{-1}$. Organic acid yields were expressed as g organic acid formed per $g$ glucose depleted per g dry cell weight (dcw). The phosphate liberated from rock phosphate in the TRP medium was measured by the Ames method (Ames, 1966).

Physiological parameters (growth rate, specific glucose depletion rate and biomass yield) were calculated as described earlier (Buch et al., 2008). The total amount of glucose depleted in the medium was obtained by deducting the value of residual glucose concentration (at the end point) from the initial glucose concentration supplied in the medium. The difference between the total glucose depleted and gluconic acid produced was considered as glucose consumed. The statistical analysis of all the parameters was done using Graph Pad Prism (version 3.0) software.

Preparation of cells/cell-free extracts and enzyme assays. M9glucose-grown cells were harvested in the appropriate growth phase from $30 \mathrm{ml}$ of cell culture by centrifugation at $9200 \mathrm{~g}$ for $2 \mathrm{~min}$ at $4{ }^{\circ} \mathrm{C}$. CS, isocitrate lyase (ICL) and ICDH were assayed in the stationary phase; other enzymes were assayed using mid- to lateexponential-phase cultures. The whole-cell preparation for GDH assay and preparation of cell-free cytosolic extracts by sonication treatment for assay of remaining enzymes were carried out as described earlier (Buch et al., 2008).

CS (2.3.3.1) activity was estimated by following the absorbance of 5,5'-dithiobis(2-nitrobenzoic acid) at $412 \mathrm{~nm}$, which would change due to its reaction with the thiol group of CoA (Serre, 1969). The assay mixture contained the following in $1.0 \mathrm{ml}$ : Tris/ $\mathrm{HCl}(\mathrm{pH} 8.0)$, $93 \mathrm{mM}$; acetyl-CoA, $0.16 \mathrm{mM}$; oxaloacetate, $0.2 \mathrm{mM}$; 5,5'-dithiobis(2-nitrobenzoic acid), $0.1 \mathrm{mM}$ and cell lysate. The reaction was started by addition of oxaloacetate. The molar absorption coefficient was taken as $13.6 \mathrm{mM}^{-1} \mathrm{~cm}^{-1}$ at $412 \mathrm{~nm}$. PPC (EC 4.1.1.31) and PYC (EC 6.4.1.1) activities were monitored by following NADH 
oxidation at $340 \mathrm{~nm}$ in an assay combined with malate dehydrogenase; G-6-PDH (EC 1.1.1.49) and ICDH (1.1.1.42) activities were determined by following the reduction of NADP at $340 \mathrm{~nm}$; ICL (4.1.3.1) activity was monitored by measuring glyoxylate formation at $324 \mathrm{~nm}$ with the aid of phenylhydrazine. $\mathrm{HCl}$; and GDH (EC 1.1.5.2) was assayed by following the coupled reduction of 2,6-dichlorophenolindophenol at $600 \mathrm{~nm}$, as described earlier (Buch et al., 2008).

All the enzyme activities were determined at $30 \pm 2{ }^{\circ} \mathrm{C}$, against appropriate controls lacking the substrate or the enzyme source in the reaction mixture. One unit of specific enzyme activity was defined as the amount of protein required to convert $1 \mathrm{nmol}$ substrate per min per mg total protein, unless specified otherwise. Total protein concentration of crude extracts and whole-cell suspensions was measured by a modified Lowry method (Peterson, 1979) using BSA as standard, with corrections made for Tris buffer.

Enzymic measurement of organic acids. Cell extracts prepared from stationary-phase cultures of $P$. fluorescens transformants grown on M9-glucose (procedures being the same as for the enzyme assays) were filtered through $0.2 \mu \mathrm{m}$ nitrocellulose membrane (continuously stored in an ice-bath or frozen until further analysis) and were used to estimate the amount of intracellular citric acid. Supernatants of the same cultures were also filtered through $0.2 \mu \mathrm{m}$ nitrocellulose membrane and were used to measure extracellular citric and pyruvic acids.

Intracellular citric acid was assayed spectrophotometrically according to the method described by Petrarulo et al. (1995) with minor modifications. The assay system contained $50 \mathrm{mM}$ phosphate buffer mix, $1.0 \mathrm{ml}$; $246 \mathrm{mM}$ phenylhydrazine, $0.02 \mathrm{ml}$; citrate lyase, $0.27 \mathrm{U}(0.02 \mathrm{ml}$ of $13.3 \mathrm{U} \mathrm{ml}^{-1}$ stock); and citric acid standard or cell extract. Buffer mix contained $50 \mathrm{mM}$ phosphate buffer ( $\mathrm{pH} 6.5$ ), $0.1 \mathrm{mM} \mathrm{ZnSO} \mathrm{Zn}_{4} \cdot 7 \mathrm{H}_{2} \mathrm{O}$ and $0.2 \mathrm{~g}$ sodium azide $\mathrm{l}^{-1}$. Citric acid standards of $5 \mu \mathrm{M}, 7.5 \mu \mathrm{M}, 10 \mu \mathrm{M}$, $15 \mu \mathrm{M}$ and $20 \mu \mathrm{M}$ were used to generate a standard curve. The difference in $A_{330} 3 \mathrm{~min}$ after addition of citrate lyase was used for calculating the intracellular citrate concentration (in $\mathrm{mM}$ ), for which cellular volume was assumed to be $1.63 \mu \mathrm{l}$ per mg dcw (Emmerling et al., 1999). Extracellular citric acid was analysed using the method involving citrate-lyase-mediated cleavage of citrate to oxaloacetate, which is subsequently utilized in a malate-dehydrogenase-catalysed reaction requiring $\mathrm{NADH}$. Change in $\mathrm{NADH}$ absorbance would be proportional to citrate concentration (Petrarulo et al., 1995; Boehringer Mannheim/R-Biopharm Enzymic BioAnalysis/Food Analysis Manual of Citric acid Determination kit, Cat. no. 10139076035$)$. The assay system per cuvette contained $50 \mathrm{mM}$ phosphate buffer mix, $1.0 \mathrm{ml}$; citrate lyase, $0.27 \mathrm{U}(0.02 \mathrm{ml}$ of $13.3 \mathrm{U}$ $\mathrm{ml}^{-1}$ stock); citric acid standard or test sample; $5 \mathrm{U}$ malate dehydrogenase; and $0.1 \mathrm{mM}$ NADH. Citric acid standards of $5 \mu \mathrm{M}, 10 \mu \mathrm{M}, 15 \mu \mathrm{M}$ and $20 \mu \mathrm{M}$ were used to generate a standard curve. The difference in $A_{340}$ 4 min after addition of citrate lyase was used for the calculations.

Pyruvic acid was estimated with lactate dehydrogenase, following the rate of NADH utilization, as described by Cocaign-Bousquet et al. (1996) with several modifications. The assay mixture contained the following in $1 \mathrm{ml}$ : Tris/ $\mathrm{HCl}(\mathrm{pH} 7.5), 200 \mathrm{mM}$; NADH, $0.12 \mathrm{mM}$; lactate dehydrogenase, $5 \mathrm{U}$; and pyruvate (variable). A standard curve prepared using known concentrations of sodium pyruvate was used to estimate pyruvate levels in the culture supernatant.

\section{RESULTS}

\section{Overexpression of $E$. coli gltA and its effect on growth, biomass and glucose utilization of P. fluorescens ATCC 13525}

The pAB7 plasmid containing the E. coli gltA gene under lac promoter control was constructed using the plasmid backbone of a broad-host-range plasmid, pUCPM18. The functional expression of $g l t A$ from $\mathrm{pAB} 7$ was confirmed by its ability to relieve the glutamate auxotrophy of the CS mutant E. coli W620 when induced with $0.1 \mathrm{mM}$ IPTG, unlike the control pAB8 plasmid which was unable to complement the mutant phenoype (unpublished results). $P$. fluorescens ATCC 13525 harbouring pAB7 [strain $P f(\mathrm{pAB} 7)]$ showed $107.30 \pm 9.7 \mathrm{U}$ of CS activity on M9 minimal medium in the presence of $100 \mathrm{mM}$ glucose, about twofold higher than that in the control $P f(\mathrm{pAB} 8)$, which showed $51.41 \pm 3.07 \mathrm{U}$ CS activity. The kinetic properties and nature of the allosteric regulation of CS in E. coli and Pseudomonas are known to be similar (Donald et al., 1989; Mitchell et al., 1995)

Both $P f(\mathrm{pAB} 7)$ and the control $P f(\mathrm{pAB} 8)$ had similar growth profiles on excess glucose and could acidify the extracellular medium within $30 \mathrm{~h}$ (Table 2; Fig. 1). Glucose consumption by $P f(\mathrm{pAB} 7)$ was reduced moderately but significantly, by $\sim 1.3$-fold as compared to $P f(\mathrm{pAB} 8)$, while growth rate, specific glucose depletion rate, biomass yield and total amount of glucose depleted after $30 \mathrm{~h}$ remained unaffected (Table 2).

\section{Effect of $E$. coli gltA overexpression on secretion of citric acid and other organic acids by P. fluorescens ATCC $\mathbf{1 3 5 2 5}$}

In order to determine the effect of increased CS activity on citric acid secretion, extracellular citric acid levels were monitored. Since E. coli icd mutants accumulated citric acid in the stationary phase, stationary-phase culture supernatants of $P f(\mathrm{pAB} 7)$ and $P f(\mathrm{pAB} 8)$ were used. Interestingly, the citric acid levels $(\sim 1.25 \pm 0.15 \mathrm{mM})$ and yield $\left[0.031 \mathrm{~g}\left(\mathrm{~g}_{\text {glucose }}\right)^{-1}(\mathrm{~g} \mathrm{dcw})^{-1}\right]$ in the extracellular medium of $P f(\mathrm{pAB} 7)$ increased by about 19 - and 26 -fold, respectively, as compared to the control $P f(\mathrm{pAB} 8)$, which secreted negligible levels of citric acid (Fig. 2a, b). Concomitantly, the intracellular citric acid levels and yields increased about 2- and 2.3-fold in $P f(\mathrm{pAB} 7)$, respectively, as compared to $P f(\mathrm{pAB} 8)$.

Culture supernatants of $P f(\mathrm{pAB} 7)$ and $P f(\mathrm{pAB} 8)$ also contained gluconic, pyruvic and acetic acids. At the end of $30 \mathrm{~h}, \mathrm{Pf}(\mathrm{pAB} 7)$ showed 2.7 - and $\sim 2.5$-fold higher levels and yield, respectively, of gluconic acid as compared to the control Pf(pAB8) (Fig. 2c, d). On the other hand, pyruvic acid levels and yield in the extracellular medium decreased significantly, by about 2.2- and 2.8-fold respectively, while acetic acid yields increased by $\sim 1.8$-fold in the gltAoverexpressing strain (Fig. 2c, d). Additionally, $P f($ pAB7) demonstrated improved phosphate-solubilizing ability as compared to its control $P f(\mathrm{pAB} 8)$, as evident from an enhanced zone of clearance on Pikovskaya's agar (Fig. 3). Under buffered conditions, $P f(\mathrm{pAB} 7)$ could release $0.92 \pm 0.15 \mu \mathrm{g}$ phosphate $(\mu \mathrm{g} \mathrm{dcw})^{-1}$ from rock phosphate after $72 \mathrm{~h}$, which was nearly 2-fold higher than the $0.50 \pm 0.06 \mu \mathrm{g}$ phosphate $(\mu \mathrm{g} \quad \mathrm{dcw})^{-1}$ released by $P f(\mathrm{pAB} 8)(n=3 ; P=0.031)$. 
Table 2. Physiological variables and metabolic data for $P$. fluorescens ATCC 13525 transformants grown on M9 minimal medium with $100 \mathrm{mM}$ glucose

The results are expressed as the mean \pm SEM of readings from six independent observations.

\begin{tabular}{|llcccc|}
\hline Bacterial strain & $\begin{array}{c}\text { Growth rate, } \\
\boldsymbol{\mu}\left(\mathbf{h}^{-\mathbf{1}}\right)^{\star}\end{array}$ & $\begin{array}{c}\text { Total glucose } \\
\mathbf{d e p l e t e d}(\mathbf{m M}) \dagger\end{array}$ & $\begin{array}{c}\text { Glucose consumed } \\
(\mathbf{m M}) \dagger\end{array}$ & $\begin{array}{c}\text { Biomass yield } \\
\boldsymbol{Y}_{\mathbf{d c w} / \mathbf{G l c}^{*}}\left(\mathbf{g ~ g}^{-\mathbf{1}}\right)\end{array}$ & $\begin{array}{c}\text { Sp. glucose depletion rate } \\
\mathbf{Q}_{\mathbf{G l c}}{ }^{*}\left[\mathbf{g}(\mathbf{g ~ d c w})^{-\mathbf{1}} \mathbf{h}^{-\mathbf{1}}\right]\end{array}$ \\
\hline$P f(\mathrm{pAB} 8)$ & $0.69 \pm 0.04$ & $66.88 \pm 3.84$ & $60.02 \pm 2.27$ & $0.15 \pm 0.02$ & $7.10 \pm 0.74$ \\
$P f(\mathrm{pAB} 7)$ & $0.75 \pm 0.04^{\mathrm{ns}}$ & $66.94 \pm 2.99^{\mathrm{ns}}$ & $50.62 \pm 1.31 \ddagger$ & $0.17 \pm 0.05^{\mathrm{ns}}$ & $8.55 \pm 1.56^{\mathrm{ns}}$ \\
$P f(\mathrm{pAB} 48)$ & $0.68 \pm 0.04$ & $61.58 \pm 3.61$ & $47.45 \pm 3.93$ & $0.14 \pm 0.02$ & $8.30 \pm 1.57$ \\
$P f(\mathrm{pAB} 37)$ & $0.69 \pm 0.03^{\mathrm{ns}}$ & $63.88 \pm 2.56^{\mathrm{ns}}$ & $52.67 \pm 3.05^{\mathrm{ns}}$ & $0.13 \pm 0.02^{\mathrm{ns}}$ & $8.32 \pm 1.32^{\mathrm{ns}}$ \\
\hline
\end{tabular}

${ }^{*}$ Determined from mid-exponential phase of each experiment.

$\dagger$ Determined at the time of $\mathrm{pH}$ drop $(30 \mathrm{~h})$.

$\ddagger P<0.01$, ns, non-significant (as compared to respective controls).

\section{Effect of $E$. coli gltA overexpression on enzymes of glucose catabolism}

The nature of the metabolic response observed in gltAoverexpressing $P$. fluorescens was investigated by assessing the specific activities of key enzymes of glucose catabolism: GDH of the periplasmic direct oxidation pathway; G-6$\mathrm{PDH}$, representing the intracellular phosphorylative pathway; enzymes at the anaplerotic node including PPC and PYC; the TCA cycle enzyme ICDH; and the glyoxylate shunt enzyme ICL. Since citric acid accumulation was monitored in stationary phase, the activities of CS, ICDH and ICL, directly involved in citrate biosynthesis and catabolism, were also determined in the stationary phase. In $P f(\mathrm{pAB} 7)$, the periplasmic GDH activity increased by $\sim 1.6$-fold while G-6$\mathrm{PDH}$ remained unaltered as compared to the control $P f($ pAB8) (Fig. 4). Interestingly, PYC activity in Pf(pAB7) increased significantly by $\sim 1.4$-fold as compared to $P f($ pAB8) while ICDH activity was unaltered. PPC and
ICL activities were negligible in $P f(\mathrm{pAB} 8)$ and were not altered in response to increased CS activity (Fig. 4).

\section{Co-expression of ppc and gltA genes in $P$. fluorescens ATCC 13525 and its effect on physiological and biochemical parameters}

Increase in PYC activity in the citric-acid-accumulating $P f($ pAB7) suggested increased cellular demands for the precursor, OAA. Hence, the S. elongatus PCC 6301 ppc gene expressed under control of the lac promoter of pUCPM18, encoding tetracycline resistance (plasmid pAB3), was introduced into P. fluorescens ATCC 13525 along with E. coli gltA. This cyanobacterial PPC is devoid of all allosteric regulation; when expressed in P. fluorescens ATCC 13525 it led to $\sim 12$-fold increase in PPC activity, and this improved the biomass yield without altering the growth or glucose depletion rates (unpublished results).

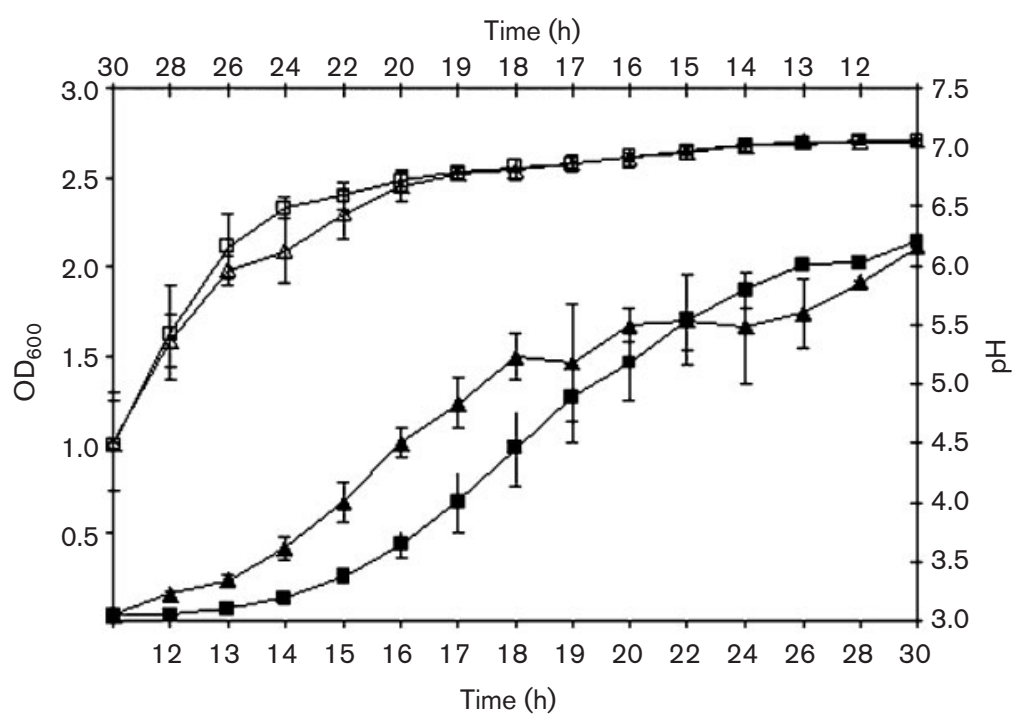

Fig. 1. Extracellular $\mathrm{pH}(\triangle, \square$; top scale) and growth profile $(\boldsymbol{\Lambda}, \mathbf{\square}$; bottom scale) of $P$. fluorescens ATCC 13525 expressing $E$. coli gltA. $\triangle, \mathbf{\Delta}$, Pf(pAB8); $\square, \mathbf{\square}, P f(\mathrm{pAB} 7) . \mathrm{OD}_{600}$ and $\mathrm{pH}$ values at each time point are represented as the mean $\pm S D$ of four to six independent observations. 

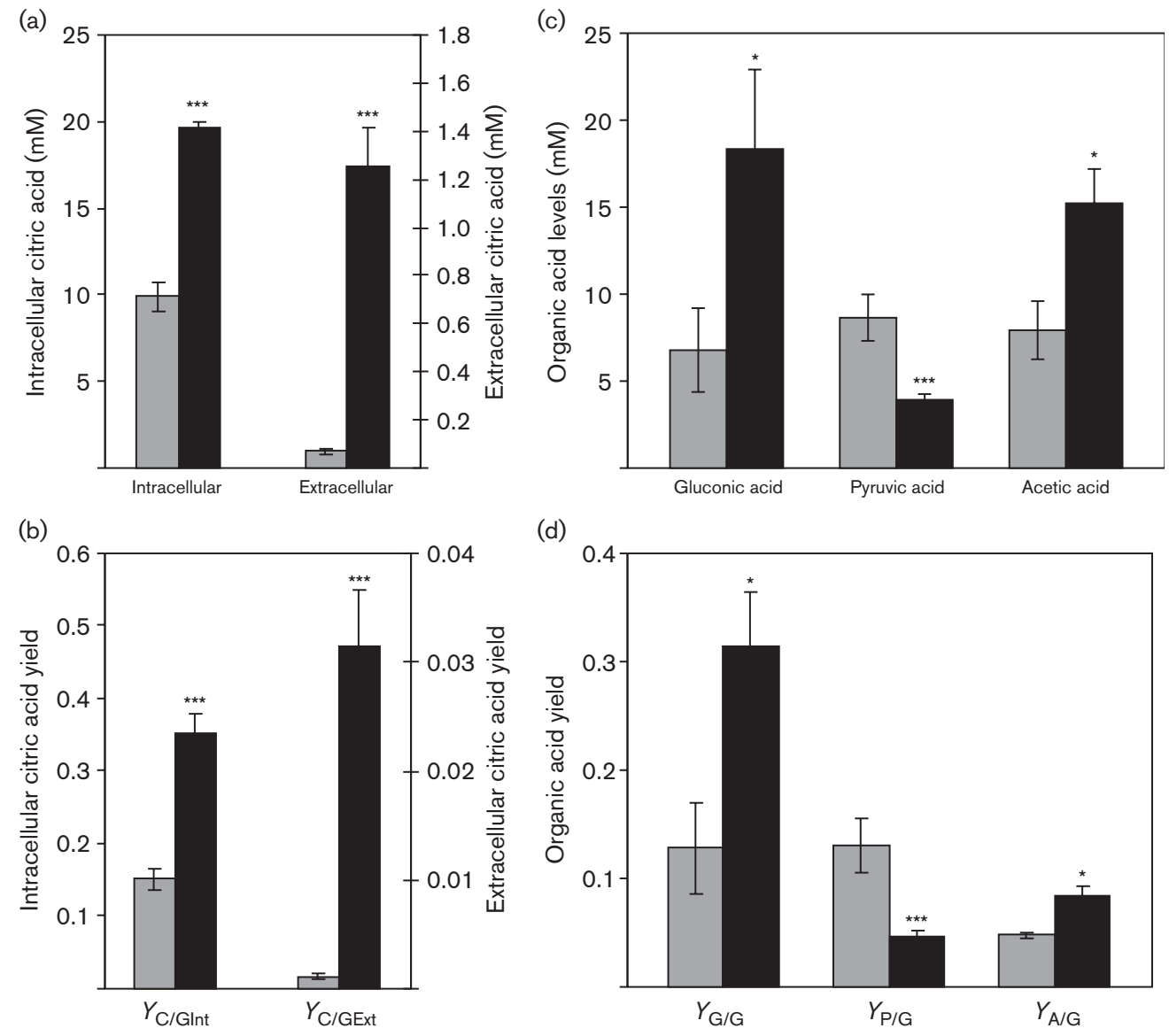

Fig. 2. Effect of $E$. coli gltA overexpression on organic acid secretion by $P$. fluorescens ATCC 13525. (a, b) Intracellular and extracellular citric acid levels and yield ( $\left.Y_{\mathrm{C} / \mathrm{Gln}}, Y_{\mathrm{C} / \mathrm{GExt}}\right)$, respectively. (c, d) Gluconic, pyruvic and acetic acids levels and yields $\left(Y_{\mathrm{G} / \mathrm{G}}, Y_{\mathrm{P} / \mathrm{G}}\right.$ and $\left.Y_{\mathrm{A} / \mathrm{G}}\right)$, respectively. Yields are expressed as $\mathrm{g}$ citric or other organic acid (g glucose $)^{-1}(\mathrm{~g} \mathrm{dcw})^{-1}$. Grey bars, $P f(p A B 8)$; black bars, $P f(p A B 7)$. The results are the mean \pm SEM of four to seven independent observations. ${ }^{*}, P<0.05$; ${ }^{\star \star \star}$, $P<0.001$.

The ppc-gltA co-expressing strain, $P f(\mathrm{pAB} 37)$, demonstrated $12.79 \pm 0.86 \mathrm{U}$ PPC and 97.69 $\pm 3.23 \mathrm{U}$ CS activities, which were $\sim 5.2$ - and $\sim 1.4$-fold higher than the corresponding control $P f(\mathrm{pAB} 48)$ (Fig. 5). Like the single transformants, $P f($ pAB37) and the control $P f($ pAB48) had similar growth profiles on excess glucose and could acidify the extracellular medium within $30 \mathrm{~h}$ (data not shown). The growth rate, specific glucose depletion rate, biomass yield, total amount of glucose depleted and glucose consumed after $30 \mathrm{~h}$ in $P f(\mathrm{pAB} 37)$ remained unaffected as compared to the control $P f(\mathrm{pAB} 48)$ (Table 2). Gluconic, pyruvic, acetic and citric acid levels and yield in the extracellular medium of $P f(\mathrm{pAB} 37)$ were unaltered as compared to $P f(\mathrm{pAB} 48)$ (Supplementary Fig. S1). Specific activities of GDH, G-6-PDH, PYC, ICDH and ICL remained unaltered in $P f(\mathrm{pAB} 37)$ as compared to $P f(\mathrm{pAB} 48)$ (Fig. 5). Again, ICL contributed negligibly to glucose catabolism.

\section{DISCUSSION}

P. fluorescens ATCC 13525 exhibited enhanced citric acid biosynthesis to overcome aluminium toxicity when grown on malate as the carbon source, by employing a unique metabolic shift involving decreased activities of enzymes utilizing oxaloacetate and citrate (phosphoenolpyruvate carboxykinase, aconitase and ICDH) with a parallel increase in activities of enzymes involved in oxaloacetate and citrate biosynthesis: malic enzyme, malate dehydrogenase and CS (Mailloux et al., 2008). On the other hand, phosphate-solubilization requires $\sim 5-10 \mathrm{mM}$ citric acid to be secreted by fluorescent pseudomonads utilizing sugars. The present study describes the metabolic changes in response to increased CS activity in P. fluorescens ATCC 13525 when grown on glucose.

The $\sim 2$-fold increase in CS activity in $P f(\mathrm{pAB} 7)$ as a result of E. coli gltA expression from the lac promoter in the 

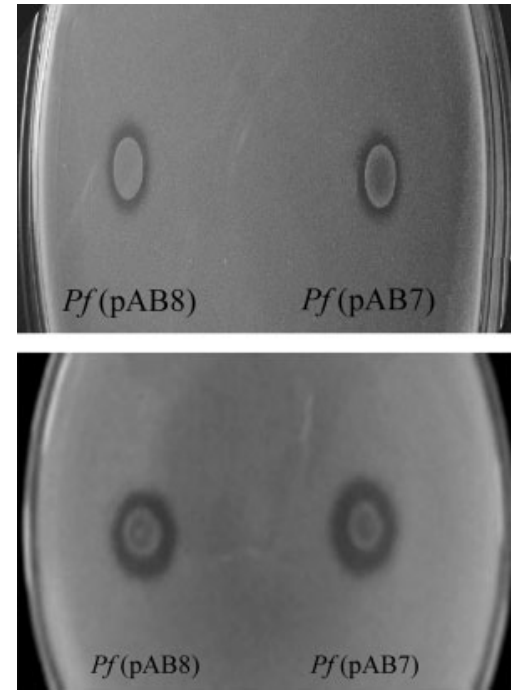

Fig. 3. Phosphate solubilization by glt $A$ transformants of $P$. fluorescens ATCC 13525: zone of clearance formed by $P f(p A B 7)$ and $P f(p A B 8)$ on Pikovskaya's agar with $12.5 \mu \mathrm{g}$ kanamycin $\mathrm{ml}^{-1}$, after incubation for $48 \mathrm{~h}$ (top) and $120 \mathrm{~h}$ (bottom), at $30{ }^{\circ} \mathrm{C}$

absence of IPTG was in accordance with the reports that the lac promoter is constitutively expressed in pseudomonads (Labes et al., 1990). Walsh \& Koshland (1985) reported a similar increase in CS activity, up to 2 -fold, by overexpression of the homologous gltA gene of E. coli under control of the tac promoter. The effect of enhanced CS activity on growth and glucose depletion rates in $P f(\mathrm{pAB} 7)$ was similar to the results of moderate ( 2-fold) overexpression of CS in E. coli (Walsh \& Koshland, 1985). Unlike in $P f(\mathrm{pAB} 7)$, in which biomass yield was unaltered, gltA overexpression in $E$. coli increased the maximum cell dry weight by $23 \%$ (De Maeseneire et al., 2006). The growth pattern suggested that glucose utilization was not subject to organic-acid-mediated catabolite repression, known to occur in pseudomonads, despite various organic acids being secreted under the experimental conditions (Basu et al., 2006). However, glucose distribution between the direct oxidative and phosphorylative pathways was altered. Reduced glucose consumption in $P f(\mathrm{pAB} 7)$ was counterbalanced by increased direct oxidative pathway activity, as evident from increased periplasmic GDH activity resulting in increased gluconic acid levels.

Remarkably, only $\sim 2$-fold increase in CS activity in $P f(\mathrm{pAB} 7)$ elevated extracellular and intracellular citric acid levels by about 15- and 2-fold, respectively, which suggested that CS activity was probably limiting for citrate accumulation in $P$. fluorescens ATCC 13525 utilizing glucose. In contrast, icd mutation was the major genetic modification, accompanied by resultant $\sim 2.5$ - and 3.8 -fold increase in CS activity, that led to citrate accumulation in E. coli $\mathrm{K}$ and B strains (Aoshima et al., 2003; Kabir \& Shimizu, 2004). Altered intracellular citric acid levels in $P f(\mathrm{pAB} 7)$ were accompanied by altered metabolite balance at the anaplerotic node, since intracellular pyruvate was diverted towards increased OAA biosynthesis to meet the increased CS activity. This was evident from increased PYC activity in $P f(\mathrm{pAB} 7)$ concomitant with reduced extracellular pyruvic acid secretion. Similar enhancement in biosynthetic reactions was also observed in E. coli $\mathrm{K}$ and $\mathrm{B} i c d$ mutants in the form of increased glyoxylate pathway activity (Aoshima et al., 2003; Kabir \& Shimizu, 2004). However, the glyoxyate shunt did not cater for the increased biosynthetic requirements in $P f(\mathrm{pAB} 7)$, as evident from the very low and unaltered ICL activity detected in $P f(\mathrm{pAB} 8)$ and $P f(\mathrm{pAB} 7)$. Low ICL activity was consistent with earlier reports on Pseudomonas indigofera, in which ICL contributed negligibly to glucose metabolism (Howes \& McFadden, 1962; Diaz-Perez et al., 2007). A parallel increase in acetic acid secretion by $P f(\mathrm{pAB} 7)$ could be the result of increased conversion of pyruvate to acetyl-

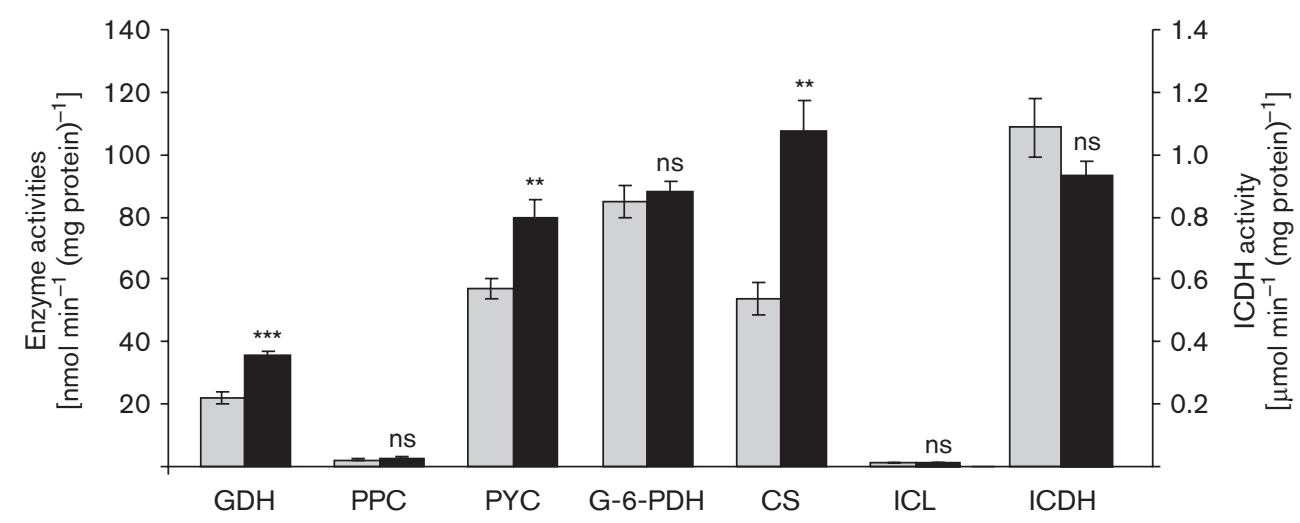

Fig. 4. Activities of key carbon utilization enzymes in $P$. fluorescens ATCC 13525 overexpressing $E$. coli gltA. Grey bars, $P f(p A B 8) ;$ black bars, $P f(p A B 7)$. The results are the mean \pm SEM of six independent observations. ${ }^{\star \star \star}, P<0.001 ;{ }^{\star \star}, P<0.01 ; n s$, non-significant. 


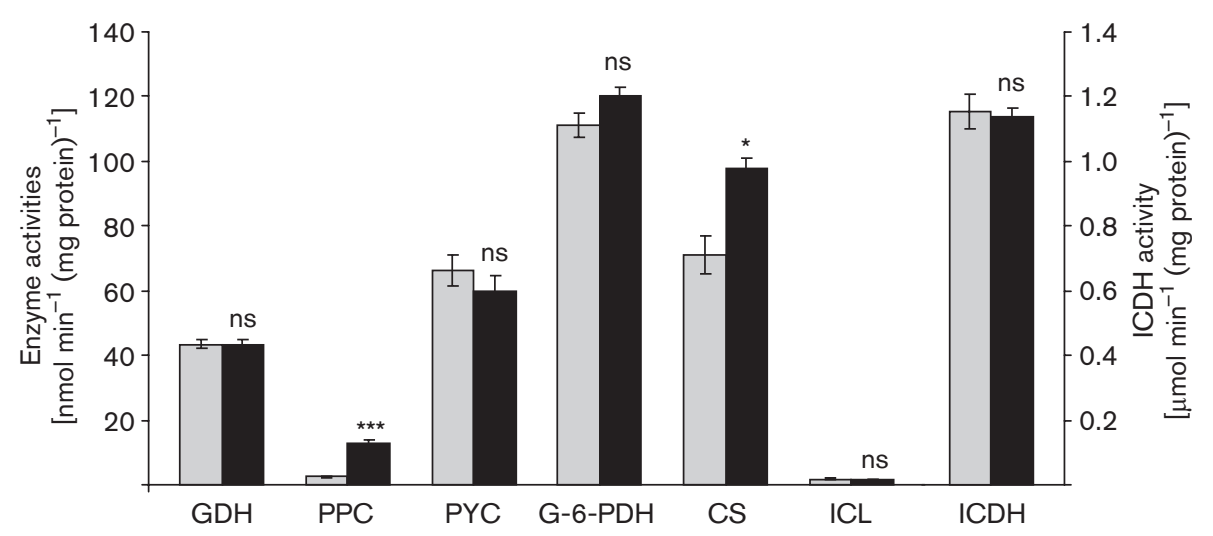

Fig. 5. Activities of key enzymes of carbon utilization in $P$. fluorescens 13525 co-expressing the $p p c$ and glt $A$ genes. Grey bars, $P f(p A B 48) ;$ black bars, $P f(p A B 37)$. The results are the mean \pm SEM of four to six independent observations. ns, non-significant.

CoA; the $\mathrm{CO}_{2}$ generated would be utilized as a co-substrate by PYC for increased OAA biosynthesis (Papagianni, 2007). In contrast, CS overexpression in E. coli reduced acetate secretion (De Maeseneire et al., 2006).

The presence of extracellular citrate in the spent medium of $P f(\mathrm{pAB} 7)$ was consistent with the presence of an inherent citrate transporter. However, considering the intracellular citrate levels in $P f(\mathrm{pAB} 7)$, relatively low extracellular citrate levels could be attributed to inefficient citrate transport; $P$. fluorescens are generally known to possess $\mathrm{H}^{+}$-dependent citrate transporters, high citrate efflux through which could be thermodynamically unfavourable (Stover et al., 2000; Nelson et al., 2002). The active transport system for citrate excretion appears to be the main rate-determining factor in citrate overproduction by yeasts (Anastassiadis \& Rehm, 2005). However, citric acid secretion by an icd mutant of $E$. coli BL21(DE3) on 2YT medium is unexplainable as it lacks a citrate transporter (van der Rest et al., 1992; Aoshima et al., 2003).

Co-expression of the $p p c$ and gltA genes in $P f(\mathrm{pAB} 37)$, although it increased the PPC and CS activities by about 5 and 1.3-fold respectively, did not alter the citrate levels as compared to $P f(\mathrm{pAB} 48)$, as evident from the unaltered metabolic profile. However, the increase in PYC activity observed in $P f(\mathrm{pAB} 7)$ was no longer found in $P f(\mathrm{pAB} 37)$. The increase in PPC and CS activities in $P f(\mathrm{pAB} 37)$ was relatively lower as compared to $P f(\mathrm{pAB} 3)$ and $P f(\mathrm{pAB} 7)$ independently overexpressing the respective genes, which could be attributed to the reduced copy numbers of the two plasmids in the double transformant $P f(\mathrm{pAB} 37)$ (data not shown). Inability of $p p c$ overexpression to increase the biomass yield in $P f(\mathrm{pAB} 37)$ as observed in $P f(\mathrm{pAB} 3)$ could be due to the channelling of the increased biosynthetic precursors to maintaining two different stably replicating plasmids.

In conclusion, CS appears to be the 'bottleneck' enzyme for TCA cycle flux in P. fluorescens grown on glucose. The present study demonstrates a direct correlation of increased CS activity and citrate accumulation, which is contrary to earlier reports from the known citric-acidproducing bacteria, in which increase in CS activity is either the result of a TCA block in the form of $i c d$ mutation as in $E$. coli or is in response to aluminium toxicity. Increasing CS activity in $P$. fluorescens for citric acid overproduction from glucose is a better strategy than icd mutation in E. coli, which reduces biomass and growth (Lakshmi \& Helling, 1976; Aoshima et al., 2003). The amount of citric acid produced by $P$. fluorescens overexpressing E. coli gltA was similar to that secreted by the PSB Bacillus coagulans and $C$. koseri on glucose (Gyaneshwar et al., 1998). Enhanced phosphate solubilization by $P f(\mathrm{pAB} 7)$ suggested that $\mathrm{CS}$ overexpression could be an interesting strategy in developing efficient phosphate-solubilizing $P$. fluorescens. Nevertheless, further studies are required to enhance the citric acid levels in the medium up to $\sim 10 \mathrm{mM}$, for developing effective phosphate-solubilizing fluorescent pseudomonads.

\section{ACKNOWLEDGEMENTS}

This work was supported by a grant from the Department of Biotechnology (DBT), Government of India.

\section{REFERENCES}

Ames, B. N. (1966). Assay of inorganic phosphate, total phosphate and phosphatases. Methods Enzymol 8, 115-118.

Anastassiadis, S. \& Rehm, H.-J. (2005). Continuous citric acid secretion by a high specific $\mathrm{pH}$ dependent active transport system in yeast Candida oleophila ATCC 20177. Electron J Biotechnol 8, 146-161.

Aoshima, M., Ishii, M., Yamagishi, A., Oshima, T. \& Igarashi, Y. (2003). Metabolic characteristics of an isocitrate dehydrogenase defective derivative of Escherichia coli BL21(DE3). Biotechnol Bioeng 84, 732-737. 
Basu, A., Apte, S. K. \& Phale, P. S. (2006). Preferential utilization of aromatic compounds over glucose by Pseudomonas putida CSV86. Appl Environ Microbiol 72, 2226-2230.

Buch, A. B., Archana, G. \& Naresh Kumar, G. (2008). Metabolic channeling of glucose towards gluconate in phosphate-solubilizing Pseudomonas aeruginosa P4 under phosphorus deficiency. Res Microbiol 159, 635-642.

Carson, K. C., Holliday, S., Glenn, A. R. \& Dilworth, M. J. (1992). Siderophore and organic acid production in root nodule bacteria. Arch Microbiol 157, 264-271.

Cocaign-Bousquet, M., Guyonvarch, A. \& Lindley, N. D. (1996). Growth rate-dependent modulation of carbon flux through central metabolism and the kinetic consequences for glucose-limited chemostat cultures of Corynebacterium glutamicum. Appl Environ Microbiol 62, 429-436.

Cohen, S. N., Chang, A. C. Y. \& Hsu, L. S. U. (1972). Nonchromosomal antibiotic resistance in bacteria: genetic transformation of Escherichia coli by R-factor DNA. Proc Natl Acad Sci U S A 69, 2110-2114.

De Maeseneire, S. L., De Mey, M., Vandedrinck, S. \& Vandamme, E. J. (2006). Metabolic characterization of E. coli citrate synthase and phosphoenolpyruvate carboxylase mutants in aerobic cultures. Biotechnol Lett 28, 1945-1953.

Diaz-Perez, A. L., Roman-Doval, C., Diaz-Perez, C., Cervantes, C., Sosa-Aguirre, C. R., Lopez-Meza, J. E. \& Campos-Garc, J. (2007). Identification of the aceA gene encoding isocitrate lyase required for the growth of Pseudomonas aeruginosa on acetate, acyclic terpenes and leucine. FEMS Microbiol Lett 269, 309-316.

Donald, L. J., Molgat, G. F. \& Duckworth, H. W. (1989). Cloning, sequencing, and expression of the gene for NADH-sensitive citrate synthase of Pseudomonas aeruginosa. J Bacteriol 171, 5542-5550.

Emmerling, M., Bailey, J. E. \& Sauer, U. (1999). Glucose catabolism of Escherichia coli strains with increased activity and altered regulation of key glycolytic enzymes. Metab Eng 1, 117-127.

Guerinot, M. L., Meidl, E. J. \& Plessner, O. (1990). Citrate as a siderophore in Bradyrhizobium japonicum. J Bacteriol 172, 3298-3303.

Gyaneshwar, P., Naresh Kumar, G. \& Parekh, L. J. (1998). Effect of buffering on the phosphate-solubilizing ability of microorganisms. World J Microbiol Biotechnol 14, 669-673.

Gyaneshwar, P., Naresh Kumar, G., Parekh, L. J. \& Poole, P. S. (2002). Role of soil microorganisms in improving $P$ nutrition of plants. Plant Soil 245, 83-93.

Haas, D. \& Défago, G. (2005). Biological control of soil-borne pathogens by fluorescent pseudomonads. Nat Rev Microbiol 3, 307-319.

Hester, K. L., Lehman, J., Najar, F., Song, L., Roe, B. A., MacGregor, C. H., Hager, P. W., Phibbs, P. V., Jr \& Sokatch, J. R. (2000). Crc is involved in catabolite repression control of the $b k d$ operons of Pseudomonas putida and Pseudomonas aeruginosa. J Bacteriol 182, 1144-1149.

Howes, W. V. \& McFadden, B. A. (1962). Isocitrate lyase and malate synthase in Pseudomonas indigofera. I. Suppression and stimulation during growth. J Bacteriol 84, 1216-1221.

Kabir, M. M. \& Shimizu, K. (2004). Metabolic regulation analysis of icd-gene knockout Escherichia coli based on 2D electrophoresis with MALDI-TOF mass spectrometry and enzyme activity measurements. Appl Microbiol Biotechnol 65, 84-96.

Khan, M. S., Zaidi, A. \& Wani, P. A. (2007). Role of phosphatesolubilizing microorganisms in sustainable agriculture - a review. Agron Sustain Dev 27, 29-43.
Kucey, R. M. N., Janzen, H. H. \& Leggett, M. E. (1989). Microbially mediated increases in plant-available phosphorus. Adv Agron 42, 199-228.

Labes, M., Pühler, A. \& Simon, R. (1990). A new family of RSF1010derived expression and lac-fusion broad-host-range vectors for gramnegative bacteria. Gene 89, 37-46.

Lakshmi, T. M. \& Helling, R. B. (1976). Selection for citrate synthase deficiency in icd mutants of Escherichia coli. J Bacteriol 127, 76-83.

Lessie, T. G. \& Phibbs, P. V., Jr (1984). Alternative pathways of carbohydrate utilization in pseudomonads. Annu Rev Microbiol 38, 359-388.

Mailloux, R. J., Lemire, J., Kalyuzhnyi, S. \& Appanna, V. (2008). A novel metabolic network leads to enhanced citrate biogenesis in Pseudomonas fluorescens exposed to aluminum toxicity. Extremophiles 12, 451-459.

Marshall, B., Stintzi, A., Gilmour, C., Meyer, J.-M. \& Poole, K. (2009). Citrate-mediated iron uptake in Pseudomonas aeruginosa: involvement of the citrate-inducible FecA receptor and the FeoB ferrous iron transporter. Microbiology 155, 305-315.

Matsuno, K., Blais, T., Serio, A. W., Conway, T., Henkin, T. M. \& Sonenshein, A. L. (1999). Metabolic imbalance and sporulation in an isocitrate dehydrogenase mutant of Bacillus subtilis. J Bacteriol 181, 3382-3391.

Mitchell, C. G., Anderson, S. C. K. \& El-Mansi, E. M. T. (1995). Purification and characterization of citrate synthase isoenzymes from Pseudomonas aeruginosa. Biochem J 309, 507-511.

Nelson, K. E., Weinel, C., Paulsen, I. T., Dodson, R. J., Hilbert, H., Martins dos Santos, V. A., Fouts, D. E., Gill, S. R., Pop, M. \& other authors (2002). Complete genome sequence and comparative analysis of the metabolically versatile Pseudomonas putida KT2440. Environ Microbiol 4, 799-808.

Papagianni, M. (2007). Advances in citric acid fermentation by Aspergillus niger: Biochemical aspects, membrane transport and modeling. Biotechnol Adv 25, 244-263.

Park, S.-J., Mccabe, J., Turana, J. \& Gunsalus, R. P. (1994). Regulation of the citrate synthase $(\mathrm{glt} A)$ gene of Escherichia coli in response to anaerobiosis and carbon supply: role of the $\operatorname{arcA}$ gene product. J Bacteriol 176, 5086-5092.

Peterson, G. L. (1979). Review of the Folin phenol quantitation method of Lowry, Rosenberg, Farr and Randall. Anal Biochem 100, 201.

Petrarulo, M., Facchini, P., Cerelli, E., Marangella, M. \& Linari, F. (1995). Citrate in urine determined with a new citrate lyase method. Clin Chem 41, 1518-1521.

Pikovskaya, R. I. (1948). Mobilization of phosphorus in soil in connection with vital activity of some microbial species. Mikrobiologiya 17, 362-370.

Rodríguez, H. \& Fraga, R. (1999). Phosphate solubilizing bacteria and their role in plant growth promotion. Biotechnol Adv 17, 319-339.

Sambrook, J. \& Russell, D. W. (2001). Molecular Cloning: a Laboratory Manual, 3rd edn. Cold Spring Harbor, NY: Cold Spring Harbor Laboratory.

Serre, P. A. (1969). Citrate synthase. Methods Enzymol 13, 3-11.

Srivastava, S., Kausalya, M. T., Archana, G., Rupela, O. P. \& Naresh Kumar, G. (2006). Efficacy of organic acid secreting bacteria in solubilization of rock phosphate in acidic alfisols. In First International Meeting on Microbial Phosphate Solubilization. Series: Developments in Plant and Soil Sciences, pp. 117-124, vol. 102. Edited by E. Velazquez \& C. Rodriguez-Barrueco. Berlin: Springer.

Stover, C. K., Pham, X. Q., Erwin, A. L., Mizoguchi, S. D., Warrener, P., Hickey, M. J., Brinkman, F. S., Hufnagle, W. O., Kowalik, D. J. \& other authors (2000). Complete genome sequence of Pseudomonas aeruginosa PA01, an opportunistic pathogen. Nature 406, 959-964. 
van der Rest, M. E., Siewe, R. M., Abee, R., Schwarz, E., Oesterhelt, D. \& Konings, W. N. (1992). Nucleotide sequence and functional properties of a sodium-dependent citrate transport system from Klebsiella pneumoniae. J Biol Chem 267, 89718989.

Viollier, P. H., Nguyen, K. T., Minas, W., Folcher, M., Dale, G. E. \&

Thompson, C. J. (2001). Roles of aconitase in growth, metabolism, and morphological differentiation of Streptomyces coelicolor. J Bacteriol 183, 3193-3203.

Walsh, K. \& Koshland, D. E., Jr (1985). Characterization of ratecontrolling steps in vivo by use of an adjustable expression vector. Proc Natl Acad Sci U S A 82, 3577-3581.

Edited by: M. A. Kertesz 